\title{
Mechanisms for accelerating the process of the infrastructure renewal
}

\author{
Inessa Lukmanova ${ }^{1}$, and Natalia Yaskova, ${ }^{2, *}$ \\ ${ }^{1}$ Moscow State University of Civil Engineering, 129337, Yaroslavskoye shosse, 26, Moscow, Russia \\ ${ }^{2}$ Russian Presidential Academy of National Economy and Public Administration, 119571, Vernadsky \\ avenue, 84, Moscow, Russia
}

\begin{abstract}
Critical deterioration of infrastructure increasingly becomes an obstacle for the development of modern Russia. Large projects in virtually all sectors of the national economy cannot be implemented without accelerating the resource turnover and reducing the delivery time of finished products to the consumer. Meanwhile, infrastructure projects are not only capital-intensive, but also pay back slowly due to objective economic and natural-climatic reasons. In addition, the current stage of the country development is characterized by the inability to achieve growth in budget expenditures for these purposes, which requires the creation of special mechanisms for investing in infrastructure projects. The practice has developed a number of approaches to solving infrastructure issues, such as the public-private partnership in the terms of concession, syndicated lending, etc. Meanwhile, the investment activity of these mechanisms is insufficient for the scale of implementation of demanded projects. The infrastructure mortgage mechanism proposed by the Ministry of Economic Development of the Russian Federation may be a solution of this problem. Debatable character of the model of implementation of infrastructure projects using mortgage instruments, the analysis of approaches and points of view of the problem and the ways of its solution allowed the authors suggesting the key measures that make it possible to give the infrastructure mortgage mechanisms a justified character in the operational mode of time.
\end{abstract}

\section{Introduction}

The issue of critical deterioration of infrastructure as a factor of slowing down the economic growth was at the forefront of the Sochi Investment Forum in 2018 [1]. Infrastructure of the country with all the accumulated problems and in all their diversity with the projected investment capacity of the required transformations from 4 to 5 trillion RUB, in the opinion of the Russian Premier D.A. Medvedev cannot be updated fragmentarily, and requires the development of a special program called the "Infrastructure Mortgage" [2]. It is quite obvious that the scale and complexity of the problem required the search for investment options in the conditions of budgetary compression. In late 2017, the Ministry of Economic Development of the Russian Federation developed a road map for the implementation of infrastructure mortgages. It is based on the proposal to create a special investment fund - an 
infrastructure mortgage fund - as a structure that accumulates investments and provides them to private partners of the program.

\section{Materials and methods}

Mechanisms for investing in the infrastructure mortgage program have become the subject of discussion and the clash of different points of view on the ways of their implementation. The Ministry of Economic Development proposed to allocate investments by providing $a$ capital grant to a private partner, which is in fact a concessionaire. The accumulation of funds in this case should be carried out by means of a bonded loan secured by state guarantees in the amount of 300 billion RUB for the period 2018-2020. The Ministry of Finance of the Russian Federation did not support the bonded loan in the conditions of the generated budget, and suggested using the mechanism of tripartite contracts. We have to note that usually the infrastructure projects, these are the projects of road and rail transport, energy, communications, and more recently, the projects of the communal and social sphere, are financed by the state. The current status of the state budget, burdened with financing of the Crimean bridge (228.3 billion RUB) and capital-intensive sports projects for the World Cup (638.4 billion RUB) [3, 4], does not allow their implementation simultaneously with infrastructure projects. It makes attracting private capitals [5].

Given the real payback period of infrastructure projects, as well as the level of their profitability and risks, it is not realistic to count on direct private investments. In this regard, the method of public-private partnership is the only way out. It allows maintaining the balance of interests of investors and users of infrastructure [6]. The use of public-private partnership implies the construction of infrastructure on credit at the lowest possible interest rates in order to minimize expenses and reduce the cost of infrastructure. In this case, the state will start payments to builders from the funds of the beneficiaries of the infrastructure. These funds are used to repay loans. At the same time, tax reliefs, which are currently being discussed, will become incentives for investors (builders). In this context, the infrastructure mortgage is essentially a modification of the public-private partnership, involving the attraction of private business for construction with the support of the state in the form of guarantees with subsequent payment after the commissioning of the facility as it is used [7, 8]. Return of capital investments is carried out by regular payments of users. Obviously, this method can also be used by natural monopolies.

\section{Results}

Regardless the possible options for investing in infrastructure projects, their main idea is to introduce a fundamentally new method of payment for the availability of a resource / service outside the concession area into the practice of public investment [9]. The infrastructure mortgage is designed for such infrastructural projects, which because of their economic nature, firstly, do not have commercial investment attraction, and secondly, they cannot be implemented through a concession mechanism. Therefore, an infrastructure mortgage is impossible and irrational where the project can be formed as a paid and investment one, for example, a toll road, a paid bridge, a transport line, etc. Everything else can theoretically be the subject of an infrastructure mortgage. In the mechanism of the Ministry of Economic Development of the Russian Federation, the mortgage is provided by an unlimited number of investors in quasi-public bonds, and an alliance of federal and regional budgets with private investors "takes" the mortgage. In discussing the mechanism of infrastructure mortgage [1], the focus was made on the choice of the project operator. For that, it was proposed to create a new state fund, which would issue quasi-government bonds for federal 
budget guarantees. A bond loan must accumulate hundreds of billions rubles needed to implement a project pool. In order to ensure liquidity of bonds, their yield should be supposedly close to the yield of federal loan bonds (OFZ). In addition, the fund's function includes the collection of applications from interested parties to finance specific infrastructure projects that cannot be implemented in existing concession terms. Based on the applications, the fund assesses potential benefits of the project for the budgets of all levels, as well as for private investors interested in participating in the infrastructure project. In the situation that the project as a whole is profitable, that is generates a stream of income from its use over a certain period, the effects of participation of the federal and local budgets, as well as investors, can and should be calculated. For example, a section of a new highway worth 100 billion RUB, presented as a project that can be implemented in three years and is calculated to be paid for ten years with interest similar to the interest in OFZ (no more than $7 \%$ per annum), is financed by $40 \%$ by the federal budget, $40 \%$ by the regional budget, and by $20 \%$ by the private investor, interested in such a road being built. If we conventionally assume a rate at which the fund, as the operator structure, takes money at the market at $7 \%$ per annum, the total cost of the project increases to 170 billion RUB. Of these, 70 billion rubles receive holders of quasi-public bonds as interests. Also in ten years the debt will be returned. Payment of mortgages per year will be 17 billion RUB, respectively [10].

The above example demonstrates the effect of a double lever. On the one hand, the infrastructure mortgage attracts the funds of private investors that realize the co-financing function; on the other hand, funds are raised through the issue of bonds under the state guarantees. According to the head of VTB A. Kostin, such a format is able to give a multiplier of eight to ten rubles for one ruble of the attracted state investments [1]. At the same time, it is clear to everyone that regardless the chosen financing mechanism (infrastructure mortgage, concession, syndicated lending, state order, etc.), a project finance management body or socalled "project financing factory" is needed.

\section{Discussion}

A comparative analysis of various approaches to the solution of the problem of financing infrastructure projects showed that, unlike concessions, an infrastructure mortgage allows concluding with construction companies not a three-year contract for the construction of the facility, but a ten-year contract for the construction and maintenance of it in good standing. In this case, the construction structures will not, as in the concession mechanism, be a weak and locally responsible party in the contract with the infrastructure owner, and will be accordingly interested not in the development of money on the short stage of the project cycle in the construction phase, but in their continued use in contracts close to the life cycle contracts. Another important advantage of infrastructure mortgages is the inclusion of some of the taxes received from the implementation of the infrastructure project in the mortgage payments. At the same time, it should be reported that this deprives the budgets of a portion of future tax revenues. The assessment of the main risks of the infrastructure mortgage mechanism showed that they, according to experts [11], fall on the federal budget. Their reduction lies in the quality and procedures for selecting projects.

While not objecting in general to the position of the Ministry of Economic Development that the country needs a set of mechanisms for selecting projects, attracting investments for their practical implementation, uniting stakeholders at all stages of the project cycle and ultimately reducing the risks of regional infrastructure deficits, the debatable issue is not only the necessity of creation of a fund and emission mechanism, but also the delimitation of the scope of infrastructure mortgages, concessions and public procurement systems. At the "Summit of Infrastructure Project Leaders", held on December 15, 2017 in Moscow, cancellation of the results of competition for the construction of Sterlitamak-Magnitogorsk 
highway made by the Department of the Federal Antimonopoly Service for Bashkiria was discussed. The Federal Antimonopoly Service of the Russian Federation considered this concession to be a state purchase and demanded a tender according to the Federal Law 44FZ of 05.04.2013. The Ministry of Economic Development of the Russian Federation and the Ministry of Transport of the Russian Federation took the opposite position. The First Deputy Prime Minister I. Shuvalov took part in the discussion and instructed the Ministry of Economic Development of the Russian Federation to draft a bill that distinguishes concessions and state purchases. Ekaterina Sorokovaia, a representative of the Department for Financial Banking and Investment Development of the Ministry of Economic Development, noted that "the reform of concessions should provide for not only the creation of a financial mechanism for more efficient use of budgetary funds and a reduction in the share of government contracts, but also a comprehensive solution of the issues of the construction and land relations" [12], but, as practice shows, the elaboration of the issues is not completed so far.

Such close attention of many ministries and departments to the idea of infrastructure mortgages can be explained by the chronic nature of the poor quality of roads, networks, social facilities, etc., which are integrated into the issue of infrastructure deficit that concerns almost all regions of the country and, in particular, the territories of advanced development (TAD). For them, the solution of infrastructure problems is the basis for the formation of a favorable investment environment and, accordingly, the growth of business activity. At the same time, it is clear to specialists and experts that lack of the necessary infrastructure for launching projects is one of the main problems in the development of TAD. According to the investment company InfraOne, the urgent need of the Far East alone (the headliner of the TAD) in the minimal estimates of infrastructure investments, by 2019 will be more than 860 billion RUB, and by 2025 their volume will grow to 970 billion RUB. Given that the budget for infrastructure has already been reduced from $3.7 \%$ of GDP in 2012 to $2.5 \%$ in 2016, the problem will be exacerbated and require immediate resolution [13].

In this case, the natural question arises: why are the specialists of the Ministry of Finance hampering the program of infrastructure mortgages? The analysis showed that:

Firstly, the intended targeted use of the budgetary funds as a source of financial support for new infrastructure projects within existing spending obligations is not possible in the framework of the federal budget's generated and accepted obligations;

Secondly, a growth of the state guarantees increases sovereign debt, which is detrimental to the country's international ratings. We should agree with the arguments of the Ministry of Finance of the Russian Federation that most points of the road map for infrastructure mortgages envisage the provision of the state support. These are mechanisms for cost recovery, tax benefits, and state guarantees;

Thirdly, the confirmation of the effectiveness of new public-private partnership mechanisms and the sources of their financial support has not even been discussed at the model level, and this is extremely important for decision-making;

Fourthly, according to the idea of the authors of the infrastructure mortgage program, support should receive the most effective and useful projects. This will help to attract financing and reduce investment risks, but so far the criteria for comparing projects have not been developed;

Fifth, the project pool did not include housing and communal services, but their wear and tear in the regions reaches $80 \%$. Also the technological features of the projects remained outside the discussion, meaning the enormous potential of the National Technology Initiative program [14].

Currently, the projects of the launch pool include:

1) Tula-Novomoskovsk toll road and regional highways;

2) The production and logistics complex of the Armed Forces in the Arkhangelsk Region; 
3) Infrastructure for the program "Digital Economy";

4) Construction of fruit and vegetable stores, etc.

Obviously, their composition does not fully reflect the variety of infrastructure facilities that need to be updated, as the Ministry of Finance of the Russian Federation said. Indeed, the list of pilot projects needs further elaboration, taking into account the scientific justification for their selection and evaluation of the financial and economic consequences of implementation for the entire range of participants.

Thus, the main claims of the expert community to the mechanisms of infrastructure mortgages can be reduced to the lack of the subject, the mechanism and regulations for the selection of infrastructure projects, scientifically substantiated and coordinated by the participants. In addition, the concentration of powers in the form of a "single window" in the curator and project coordinator in the Ministry of Economic Development of the Russian Federation, apart from the relevant ministries and departments (the Ministry of Construction of the Russian Federation, the Ministry of Energy of the Russian Federation, the Ministry of Transport of the Russian Federation, the Ministry of Agriculture of the Russian Federation, etc.) will not allow taking into full account their specificity and economic potential.

It is also important to note that in the main discussion clip, there is no voice of the construction industry as a whole and of construction and design companies in particular. Meanwhile, without their activities, the construction phase of the project cycle cannot be implemented. Moreover, project miscalculations are reflected at all stages of the life cycle of the project [15].

It is also completely unclear to what extent the powers of the Project Management Department of the government apparatus will be realized and how the powers between state bodies, private investors and banks will be distributed. The format and nature of the state support also require clarification.

\section{Conclusion}

Summarizing the discussion of the infrastructure mortgage program, it should be noted that:

First, the very idea of an infrastructure mortgage is timely and relevant in connection with the severity of the problem and fundamental impossibility of implementing high-tech breakthrough projects of the country's development without adequate infrastructure;

Second, for modelling the infrastructure mortgage mechanism, the best practices should be studied and evaluated by experts and, if approved, adapted to use in the Russian conditions;

Third, the road map for the introduction of infrastructure mortgages should be developed on a competitive basis and contain a mandatory justification for the mechanisms for cost recovery, tax benefits, state guarantees, etc. It should have calculated evidences of the effectiveness and a detailed description of public-private partnership instruments, proposals for financial sources, and so on;

Fourth, public hearings should be held with the involvement of stakeholders (representatives of regions, municipalities, investors, etc.), as well as profile experts on the entire range of projects and options for mechanisms to activate infrastructure mortgages;

Fifth, it is necessary to approve the criteria and procedure for selecting projects of infrastructure mortgages with the involvement of relevant experts;

Sixth, it is necessary to adopt legislative amendments that differentiate the spheres the state contracts, concessions and infrastructure mortgages;

Seventh, it is needed to ensure the creation of a project finance factory as an infrastructure mortgage management body with a representation of the construction industry, banking community and development institutions. 
The implementation of the proposed measures will make it possible to provide the new mechanism of infrastructure mortgages with the complex character for the sound selection of projects, economically feasible emission, and mutual responsibility for the final result, namely, the creation of infrastructure on a new technological basis.

\section{References}

1. XVII International Investment Forum Sochi-2018 (http://forum-in-sochi.ru/, 2018)

2. Minecom prepared an infrastructure mortgage plan (http://finamz.ru/2017/11/28/minek-podgotovil-plan-infrastrukturnoj-ipoteki, 2018)

3. The construction of the Crimean bridge across the Kerch Strait to the end of the final (http://www.1rre.ru/72991-krymskij-most-obeshhayut-dostroit-v-oglashennyj-srok-na2018-god.html, 2018)

4. Cost of the World Cup 2018 (https://og.ru/sports/2017/02/06/86672, 2018)

5. M. I. Kamenetskiy, N. Yu. Yaskova, Scientific Papers: Institute of Economic Forecasting of the Russian Academy of Sciences, 10, 243-256 (2012)

6. D. M. Karasik, N. Yu. Yaskova, Scientific Review, 6, 115-119 (2013)

7. E. Istrate, R. Puentes. Moving forward on public private oartnerships: U.S. and international experience with PPP units (Brookings Institute, Washington, DC, 2011)

8. C. Farrugia, T. Reynolds, R. Orr, Public private partnership agencies: a global perspective (Stanford University, Stanford, CA. 2008)

9. The Federal Law on Concession Agreements No. 115-FZ of July 21, 2005 (latest version) (http://www.consultant.ru/document/cons_doc_LAW_54572, 2018)

10. When the state takes a mortgage (https://www.kommersant.ru/doc/3546759, 2018)

11. The market is cautious about Putin's proposed infrastructure mortgage (https://www. vedomosti.ru/economics/articles/2017/06/05/692947-infrastrukturnoi-ipoteke, 2017)

12. Summit of Infrastructure Project Leaders (https://investinfra.ru/kalendar-meropriyatiy/ sammit-liderov-rynka-infrastruktur-nyh-proektov-infrasummit.html, 2018)

13. Current pipes do not offer (http://m.profile.ru/economics/item/124265-tekushchie-tru by-ne-predlagat, 2018)

14. Federal State Statistics Service (http://www.gks.ru, 2018)

15. National Technology Initiative (http://asi.ru/nti/, 2018).

16. N. Yu. Yaskova, Vestnik MGSU, 6 (105), 680-686 (2017). 